\title{
CLEANING ABILITY OF CHLORHEXIDINE GEL AND SODIUM HYPOCHLORITE ASSOCIATED OR NOT WITH EDTAAS ROOT CANAL IRRIGANTS: A SCANNING ELECTRON MICROSCOPY STUDY
}

\author{
Bruno Carvalho de VASCONCELOS ${ }^{1}$, Suyane Maria LUNA-CRUZ ${ }^{2}$, Gustavo DE-DEUS ${ }^{3}$, Ivaldo Gomes de MORAES ${ }^{4}$, \\ Claudio MANIGLIA-FERREIRA ${ }^{5}$, Eduardo Diogo GURGEL-FILHO
}

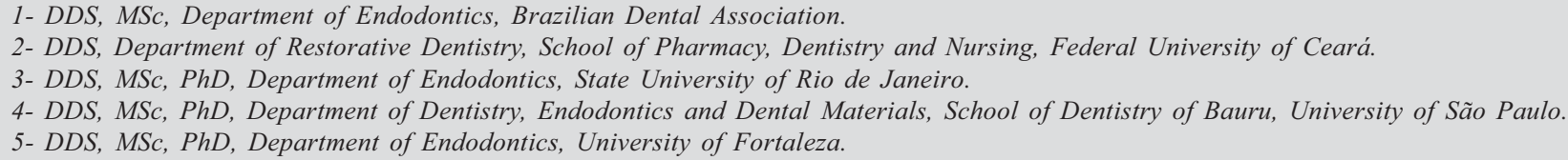

Corresponding address: Bruno C. de Vasconcelos - Departamento de Endodontia, Associação Brasileira de Odontologia, R. Ana Bilhar, $\mathrm{n}$. 940, Apt. 704, Fortaleza, Ceará, ZIP CODE: 60160-110, Brasil - Phone/Fax: 558532421329 - e-mail bcv@usp.br.

Received: April 11, 2007 - Modification: June 18, 2007 - Accept: July 11, 2007

\begin{abstract}
$T_{\text {he }}$ The aim of this study was to evaluate the cleaning efficacy of $2 \%$ chlorhexidine gluconate gel (CHX) compared to $2.5 \%$ sodium hypochlorite solution $(\mathrm{NaOCl})$ associated or not with $17 \%$ EDTA used as irrigants during the biomechanical preparation. Fifty freshly extracted single-rooted human teeth with complete apex formation were randomly divided into five groups: G1 sterile saline, G2 - 2.5\% NaOCl, G3 - 2\% CHX, G4 - 2.5\% NaOCl + EDTA and G5 - 2\% CHX + EDTA. The specimens of G1 were subdivided into two control groups. The teeth were decoronated and the coronal and middle root thirds were prepared with Gates-Glidden burs, and the apical third was reserved to manual instrumentation. All procedures were performed by a single operator. In all groups, $2 \mathrm{~mL}$ of irrigant was delivered between each file change. The teeth were sectioned and prepared for analyses under scanning electron microscopy (SEM). SEM micrographs were graded according to a score scale by two examiners. Data were analyzed statistically by Kruskal-Wallis and Dunn tests at $1 \%$ significance level. The best results were obtained in the groups in which the irrigant was used followed by the chelating agent. No statistically significant difference was observed among G4, G5 and the positive control group $(\mathrm{p}<0.01)$. The groups $\mathrm{G} 2$ and G3 were significantly different from the others, presenting the worst cleaning capacity. In conclusion, the use of the chelating agent is necessary to obtain clean canal walls, with open tubules and no heavy debris. The use of $2 \%$ chlorhexidine gluconate gel alone is not able to remove the smear layer.
\end{abstract}

Uniterms: Root canal preparation; Root canal irrigation; Root canal cleaning.

\section{INTRODUCTION}

The presence of bacteria and their byproducts in the development of pulp and periapical lesions is well established $^{12}$. Therefore, one of the objectives of endodontic treatment is the elimination of microorganisms from the root canal system. However, no instrumentation technique or irrigating solution is able to totally eliminate these microorganisms or their toxins ${ }^{20,22}$.

After biomechanical preparation, residual pulp tissue, bacteria and dentin chips may persist in the irregularities of the root canal system, covering the canal walls or lodged in the dentinal tubules even after careful instrumentation ${ }^{1,22,23}$.
The presence of smear layer and debris decreases the penetration ability of intracanal dressings and also prevents complete adaptation of obturation materials ${ }^{5,25,28}$. An irrigant that could completely remove the smear layer would contribute to reduce the microbiota and associated endotoxins and decrease the potential of bacteria to survive and reproduce ${ }^{13}$.

Selection of irrigants is very important because they can act as lubricants during instrumentation, remove the debris and necrotic pulp tissue and help eliminating or neutralizing microorganisms and their byproducts ${ }^{7,28,31}$.

The most popular endodontic irrigant is sodium hypochlorite $(\mathrm{NaOCl})^{3,32}$. The large use of $\mathrm{NaOCl}$ is related 
to its great physicochemical, antibacterial and tissue dissolving properties. Nevertheless, it is know to be highly irritating to the periapical tissues when used at high concentrations $^{6,17}$. It has undesirable characteristics such as toxicity, risk of emphysema, allergic potential and unpleasant smell and taste $6,11,31$.

Chlorhexidine gluconate has been extensively used in dentistry, showing good results in caries control and as an aid in periodontal therapy ${ }^{31}$. It has been suggested as an endodontic irrigant, in liquid or gel form, as an alternative to $\mathrm{NaOCl}$, because it has a broad-spectrum antimicrobial effect, presents residual action and biocompatibility, and has great physicochemical properties ${ }^{4,9,15,27,29}$.

The capacity of chlorhexidine gluconate gel to remove the smear layer is not yet clear and the literature brings ambiguous results of the cleaning ability of this substance as an endodontic irrigant ${ }^{7,14,20,31}$. Thus, the purpose of this study was to evaluate the efficacy of cleaning and flushing of debris of $2 \%$ chlorhexidine gluconate gel and $2.5 \% \mathrm{NaOCl}$ associated or not to $17 \%$ EDTA.

\section{MATERIAL AND METHODS}

Fifty freshly extracted, single-rooted human teeth with complete apex formation were used. The study was approved by the institutional Ethics Committee. The crowns were sectioned with a bur in a low-speed handpiece producing 17-mm root specimens.

Roots were randomly divided into five groups, with ten roots each: group 1 (G1) sterile saline (Farmence, Barbalha, $\mathrm{CE}$, Brazil); group 2 (G2) 2.5\% NaOCl (Biodinâmica, Ibiporã, PR, Brazil); group 3 (G3) 2\% chlorhexidine gluconate gel (Essencial Farma, Itapetininga, SP, Brazil); group 4 (G4) 2.5\% $\mathrm{NaOCl}$ followed by $17 \%$ EDTA(Biodinâmica, Ibiporã, PR, Brazil); and group 5 (G5) 2\% chlorhexidine gluconate gel followed by $17 \%$ EDTA(Biodinâmica, Ibiporã, PR, Brazil). The teeth in G1 were subdivided into two control groups $(n=5)$ : a negative control group, irrigated only with sterile saline; and a positive control group irrigated with sterile saline and submitted, after preparation, to a 5-miniute ultrasonic bath in $2.5 \% \mathrm{NaOCl}$, followed by an additional 1 minute bath in $17 \%$ EDTA.

Mechanical preparation was performed by a single operator according to a crown-down technique. The coronal and middle root thirds were prepared with Gates-Glidden burs (Dentsply/Maillefer, Ballaigues, Switzerland) used in decreasing order: GG\#6, GG\#5, GG\#4, GG\#3 ${ }^{8}$. Manual instrumentation was performed on the apical third with sizes \#60, \#55, \#50 and \#45 K-files(Dentsply/Maillefer, Ballaigues, Switzerland), using the balanced force technique. In all experimental groups, $2 \mathrm{~mL}$ of freshly prepared irrigant were applied between each change of instrument or bur, and a final flush was performed with $3 \mathrm{~mL}$ of sterile saline. In groups G4 and G5, the chelating agent was used during 3 minutes under agitation performed with a \#30 K-file (Dentsply/ Maillefer, Ballaigues, Switzerland), followed by another flush with $3 \mathrm{~mL}$ of sterile saline ${ }^{31}$. Irrigation was performed using
10-mL disposable syringes with 20x5.5 disposable needles without bevel (Becton Dickinsin, Juiz de Fora, MG, Brazil).

The canals were dried with paper points and the roots were split along the long axis in a buccolingual direction. The root halves were mounted with conductive adhesive onto metal stubs, sputter-coated with gold and examined on a scanning electron microscope (Zeiss DSM 940A, Jena, Germany). The entire surface of the apical third of each half was examined at $\mathrm{x} 12$ to $\mathrm{x} 1500$ magnifications and then, micrographs were taken at $\mathrm{x} 1000$ magnification.

The evaluation was performed by classification of the root canal surfaces in different levels of amount of smear layer and debris by two examiners in a double-blind design. The root canal walls were then graded according to Ahlquist, et al. ${ }^{2}$ (2001), as follows: for the presence of smear layer, $1=$ no smear layer, open dentinal tubules; 2 = little smear layer, most dentinal tubules were open; 3 = homogeneous smear layer covering most part of the surface, a few tubules open; $4=$ homogeneous smear layer covering the surface, no dentinal tubules open; 5 = thick non-homogeneous smear layer covering the surface; for the presence of debris, $1=$ clean root canal wall, very little amount of debris; 2 = little amount of debris; 3 = moderate amount of debris, less than $50 \%$ of the specimen surface covered; $4=$ substantial amount of debris, more than $50 \%$ of the specimen surface covered; $5=$ the root specimen surface was completely or almost completely covered with debris.

Data were statistically analyzed using the Kruskal-Wallis and Dunn tests, applied at a significance level of $1 \%(\mathrm{p}<0.01)$ as data were not normally distributed. In addition, the degrees of inter and intra-examiner reliability was assessed by calculating Kappa values.

\section{RESULTS}

Statistical analysis confirmed the reliability of the method, as the Kappa values were higher than 0.9 for both intra and inter-examiner, indicating high observer agreement. Table 1 shows the values of median and medium post for each group, besides the statistical differences. The analysis of the specimens in the positive control group showed that all surfaces were totally clean and free from smear layer and debris (Figure 1A), without any signs of covered dentinal tubules. In the specimens of the negative control group, the canal walls were totally covered by smear layer and debris were formed over the inner surface of dentinal walls (Figure $1 \mathrm{~F})$.

The analysis of groups G4 and G5, respectively treated with $2.5 \% \mathrm{NaOCl}$ and $2 \%$ chlorhexidine gluconate gel followed by $17 \%$ EDTA (Figures. $1 \mathrm{~B}$ and $1 \mathrm{C}$ ), showed no statistically significant difference between them and the positive control group, presenting the best results $(\mathrm{p}<0.01)$. Generally, there was typical thin smear layer and light debris formed by mechanical preparation. Most dentinal tubules of these specimens were open.

The specimens in $\mathrm{G} 2$ and $\mathrm{G} 3$, respectively irrigated only with $2.5 \% \mathrm{NaOCl}$ and $2 \%$ chlorhexidine gluconate gel 
(Figures. 1D and 1E), showed the worst results, with no significant difference $(p<0.01)$ between them and the negative control group. In general, these specimens showed heavy smear layer and debris covering the openings of dentinal tubules; at some areas, the debris and smear layer produced by biomechanical preparation partially covered the dentinal walls. Some dentinal tubules were open and some were covered.

\section{DISCUSSION}

A laboratory test is only the first step in the investigation of efficacy of irrigants ${ }^{4}$. The SEM analysis is probably the best tool to identify organic and inorganic debris and smear layer on the root canal walls after endodontic preparation, producing high resolution and magnification images ${ }^{8}$. However, other methods can be found in the literature, as light microscopic evaluation, so, currently there is no consensus on the standardization of methods for measurement of intracanal debris and smear layer ${ }^{4,7,8}$. Although SEM analysis represents the most popular

TABLE 1- Values of median and mean post for the presence of smear layer and debris for each group

\begin{tabular}{|c|c|c|c|c|}
\hline \multirow[t]{2}{*}{ Group } & \multicolumn{2}{|c|}{ Smear layer } & \multicolumn{2}{|c|}{ Debris } \\
\hline & Median & Mean Post & Median & Mean Post \\
\hline C- & 4 & $188.54_{a}$ & 3 & $202.78_{a}$ \\
\hline G2 & 4 & $204.59_{a}$ & 3 & $181.81_{a}$ \\
\hline G3 & 4 & $185.23_{a}$ & 3 & $177.31_{a}$ \\
\hline G4 & 2 & $74.95_{b}$ & 2 & $101.82_{b}$ \\
\hline G5 & 2 & $90.26_{b}$ & 2 & $88.69_{b}$ \\
\hline $\mathrm{C}+$ & 2 & $53.59_{b}$ & 1 & $41.22_{b}$ \\
\hline
\end{tabular}

Different letters indicate statistically significant difference $(p<0.01$; Kruskall Wallis test).
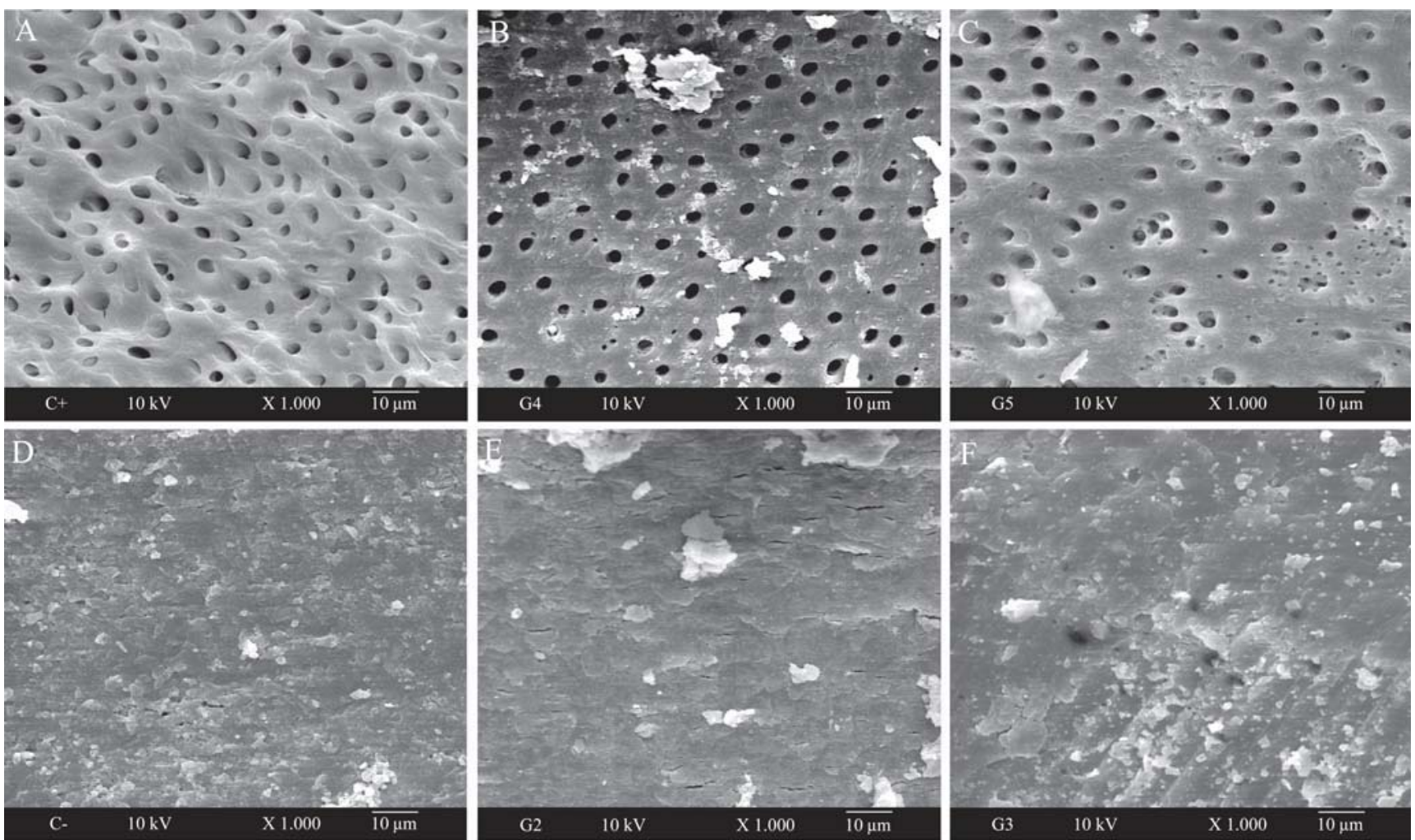

FIGURE 1- SEM micrographs of the groups. (A) Positive control group showing canal walls totally free of debris or smear layer, all tubules opened. (B-C) Typical thin smear layer and little amount of debris, with open dentinal tubules. (D) Negative control group showing canal walls covered by smear layer and debris with no open tubules. (E-F) Heavy smear layer and debris covering the dentinal walls, with a small number of open dentinal tubules 
method to identify debris and smear layer, light microscopic evaluation could probably archive more consistent results in the identification of organic particles that represents minor part of them ${ }^{16}$.

Several models have been suggested for ex vivo investigation of the cleaning efficacy. However, most studies obtained micrographs from the middle root third ${ }^{2,28,30,31}$. Although this study analyzed only the apical third, this fact was based on the literature, which states that worst cleaning results are observed at the apical third ${ }^{2,28,30,31}$. This may be related to the decreasing diameter of the root canal and consequent decrease in flow of the irrigant, concomitant with the smallest diameter of tubules in that portion. In order to evaluate the efficacy for cleaning the canals and flushing away debris, this study used a score scale according to Ahlquist, et al. ${ }^{2}$ (2001). This scale was used because it was clear and easy to learn, which was confirmed by the high Kappa values.

Several irrigants have been suggested for use during and after root canal preparation not only as antimicrobial agents, but also to increase the cutting efficiency of root canal instruments, remove smear layer and flush away the debris. $\mathrm{NaOCl}$ has been the irrigant of choice for endodontic treatment for several decades because of its excellent properties of organic tissue dissolution and antimicrobial activity ${ }^{11,31}$. Chlorhexidine gluconate is a cationic bisguanide that causes leakage of intracellular components and, if used as a water-soluble gel, as Natrosol, it is able to aggregate dentin chips, decreasing the production of smear layer and debris, without the outcome of other gel-based solutions ${ }^{7}$. In addition, a previous study showed that this gel did not interfere with the capacity of sealers to fill artificially lateral canals mechanically prepared with $\mathrm{it}^{26}$.

Debris is defined as dentin chips, pulp remnants or other particles loosely found on the root canal walls ${ }^{10}$. On the other hand, smear layer is defined as a film of debris intensely attached to the dentin and other surfaces following instrumentation with rotary drills or endodontic files, being composed of dentin particles, remnants of vital or necrotic pulp tissue, bacterial products and retained irrigants ${ }^{18}$. Therefore, in an infected root canal, the smear layer and debris should be removed to eliminate bacteria, facilitate the action of intracanal medicaments, and improve the sealing of obturation materials ${ }^{24}$.

The results of the present study showed that when $2.5 \%$ $\mathrm{NaOCl}$ and 2\% chlorhexidine gluconate gel were used without $17 \%$ EDTA, they did not efficiently remove the smear layer and debris, these findings corroborate those of Yamashita, et al..$^{31}$ (2003), Menezes, et al..$^{20}$ (2003), Medici; Fröner ${ }^{19}$ (2006), who advocate the use of a mixture or combination of one of those solutions and chelating substances to reach improve action on the smear layer. These authors attribute to the chelating agent the capacity to remove the major component of the smear layer and debris, the inorganic components, favoring the action of others solutions. On the other hand, Ferraz, et al. ${ }^{7}$ (2001) reported better cleaning results using $2 \%$ chlorhexidine gluconate gel compared to $5.25 \% \mathrm{NaOCl}$ or $2 \%$ chlorhexidine gluconate in liquid form. In their study, Ferraz, et al. ${ }^{7}$ (2001) submitted the specimens to a previous ultrasonic bath, which might probably have opened the tubules that were maintained free of smear and debris during the preparation, whereas, in this present study, the specimens did not receive any type of previous treatment, which can explain the different outcomes.

In the present study, the root canal walls were free of smear layer and debris only when the irrigant was followed by $17 \%$ EDTA, independently of the type of irrigating solution employed. The root canal walls were almost always free of residues, and the dentinal tubules were visible. These results are in agreement with those of other authors, who have also reported that the removal inorganic residues is mainly dependent on the action of chelating agents ${ }^{24,28,30}$. As the smear layer is mostly composed of $70 \%$ of inorganic particles $^{21}$, the performance of the irrigating solutions can be explained by the inability of both products to remove this type of residues.

\section{CONCLUSIONS}

Under the tested conditions, it may be concluded that the use of $2.5 \%$ sodium hypochlorite or $2 \%$ chlorhexidine gluconate gel as irrigating solutions without association with a chelating agent was not effective in smear layer or debris removal. Thus, use of a chelating agent can contribute significantly for achievement of clean root canal walls with open tubules.

\section{ACKNOWLEDGMENT}

The authors are grateful to NAP/MEPA - ESALQ/USP for the SEM technical support.

\section{REFERENCES}

1- Abou-Rass M, Piccinino M. The effectiveness of four clinical irrigation methods on the removal of root debris. Oral Surg Oral Med Oral Pathol. 1982;53:524-8.

2- Ahlquist M, Henningsson O, Hultenby K, Ohlin J. The effectiveness of manual and rotary techniques in the cleaning of root canals: a scanning electron microscopy study. Int Endod J. 2001;34:533-7.

3- Ayhan H, Sultan N, Cirak M, Ruhi MZ, Bodur H. Antimicrobial effects of various endodontic irrigants on selected microorganisms. Int Endod J. 1999;32:99-102.

4- Bondestam O, Gahnberg L, Sund ML, Linder L. Effect of chlorhexidine gel treatment on the prevalence of Mutans streptococci and lactobacilli in patients with impared salivary secretion rate. Spec Care Dentist. 1996;16:123-7.

5- De Deus G, Gurgel Filho ED, Ferreira CM, Coutinho Filho T. Intratubular penetration of root canal sealers. Pesq Odontol Bras. 2002;16:332-6. 
6- Ercan E, Ozekinci T, Atakul F, Gul K. Antibacterial activity of 2\% chlorhexidine gluconate and $5.25 \%$ sodium hypochlorite in infected root canal: in vivo study. J Endod. 2004;30:84-7.

7- Ferraz CCR, Gomes BPFA, Zaia AA, Texeira FB, Souza-Filho FJ. In vitro assessment of the antimicrobial action and the mechanical ability of chlorhexidine gel as an endodontic irrigant. J Endod. 2001;27:452-5

8- Goering AC, Michelich RJ, Schultz HH. Instrumentation of root canals in molars using the step-down technique. J Endod. 1982;8:550-

9- Gomes BPFA, Ferraz CCR, Vianna ME, Berber VB, Texeira FB, Souza-Filho FJ. In vitro antimicrobial activity of several concentrations of sodium hypochlorite and chlorhexidine gluconate in the elimination of Enterococcus faecalis. Int Endod J. 2001;34:424 8 .

10 - Hülsmann M, Rümmelin C, Schäfers F. Root canal cleanliness after preparation with different endodontic handpieces and hand instruments: a comparative SEM investigation. J Endod. 1997;23:301-

11 - Jeansonne MJ, White RR. A comparison of $2.0 \%$ chlorhexidine gluconate and $5.25 \%$ sodium hypochlorite as antimicrobial endodontic irrigants. J Endod. 1994;20:276-8.

12 - Kakehashi S, Stanley HR, Fitzgerald RJ. The effect of surgical exposures of dental pulps in germ-free and conventional laboratory rats. Oral Surg Oral Med Oral Pathol. 1965;20:340-4.

13- Lenarda, R, Cadenaro M, Sbaziero O. Effectiveness of $1 \mathrm{~mol} \mathrm{~L}^{-1}$ citric acid and $15 \%$ EDTA irrigation on smear layer removal. Int Endod J. 2000;33:46-52.

14- Leonardo MR, Bezerra da Silva RA, Assed S, Nelson-Filho P. Importance of bacterial endotoxin (LPS) in endodontics. J Appl Oral Sci. 2004;12:93-8.

15- Leonardo MR, Tanomaru-Filho M, Silva LAB, Nelson-Filho O, Bonifácio $\mathrm{KC}$, ITO IY. In vivo antimicrobial activity of $2 \%$ chlorhexidine used as a root canal irrigating solution. J Endod. 1999;25:167-71.

16- Lim, TS, Wee TY, Choi MY, Koh WC, Sae-Lim V. Light and Scanning electron microscopic evaluation of Glyde File Prep in smear layer removal. Int Endod J. 2003;36:336-43.

17- Marais JT. Cleaning efficacy of a new root canal irrigation solution: a preliminary evaluation. Int Endod J. 2000;33:320-5.

18-McComb D, Smith DC. A preliminary scanning electron microscopic study of root canals after endodontic procedures. J Endod. $1975 ; 1: 238-42$

19- Medici MC, Fröner IC. A scanning electron microscopic evaluation of different root canal irrigation regimens. Braz Oral Res. 2006;20:235-40

20- Menezes ACSC, Zanet, CG, Valera, MC. Smear layer removal capacity of disinfectant solutions used with and without EDTA for the irrigation of canals: a SEM study. Pesqui Odontol Bras. 2003;17:349-55.

21 - Pashley DH. Smear layer: overview of structure and function. Proc Finn Dent Soc. 1992;88:215-24.

22- Peters LB, Wesselink PR. Periapical healing of endodontically treated teeth in one and two visits obturated in the presence or absence of detectable microorganisms. Int Endod J. 2002;35:660-7.
23- Peters LB, Wesselink PR, Moorer WR. The fate and the role of bacteria left in root dentinal tubules. Int Endod J. 1995;28:95-9

24-Sen BH, Wesselink PR, Türkün M. The smear layer: a phenomenon in root canal therapy. Int Endod J. 1995;28:141-8.

25- Shahravan A, Haghdoost A, Adl A, Rahimi H, Shadifar F. Effect of smear layer on sealing ability of canal obturation: a systematic review and meta-analysis. J Endod. 2007;33:96-105.

26- Silva DR, Moraes IG. Influence of different auxiliary agents of biomechanical preparation in the filling of artificially prepared" lateral canals. J Appl Oral Sci. 2005;13:147-51

27- Tanomaru-Filho M, Leonardo MR, Silva LAB, Aníbal FF, Faccioli LH. Inflamatory response to different endodontic irragation solutions. Int Endod J. 2002;35:735-9.

28- Torabinejad M, Khademi AA, Babagoli J, Cho Y, Johnson WB, Bozhilov K, Kim J Shabahang S. A new solution for the removal of the smear layer. J Endod. 2003;29:170-5.

29- White RR, Hays GL, Janer LR. Residual antimicrobial activity after canal irrigation with chlorhexidine. J Endod. 1997;23:229-31.

30- Yamada RS, Armas A, Goldman M. Lin PS. A scanning electron microscopic comparison of a high volume final flush with several irrigation solutions: part 3. J Endod. 1983;9:137-42.

31 - Yamashita JC, Tanomaru-Filho M, Leonardo MR, Rossi MA, Silva LAB. Scanning electron microscopic study of the cleaning ability of chlorhexidine as a root-canal irrigant. Int Endod J. 2003;36:391-

32- Yeselsoy C, Whitaker E, Cleveland D, Phillips E, Trope M. Antimicrobial and toxic effects of established and potential root canal irrigants. J Endod. 1995;21:513-5. 